IZVORNI NAUČNI ČLANAK

Doc. dr Jelena Simić*

\title{
THE PROTECTION OF NASCITURUS WITHIN THE CIVIL LAW
}

\begin{abstract}
Modern constitutions of civilized countries guarantee every person's right to life, physical and mental integrity. Since constitutional norms guarantee the protection of "human" life, this led to the question: "At what point is 'human' life considered to begin?" A grand majority of legal regulations is intended for people who are already born, which is why it is often questioned whether they are adequate for the unborn, i.e. what position contemporary legal systems occupy toward conceived and unborn human life. This paper attempts to answer the question whether the legal rule "he who causes damage must compensate for it" can be applied in case of a conceived and unborn person; i.e. if an embryo, considering that it has not become a legal subject, could claim the position of "other", i.e. a human? Analyzing the German legal theory and case law, the author concludes that the civil law protects nasciturus from harm inflicted on their body or health, so a positive answer to the question could be given only from the point of view that for the right to compensation it is of little consequence when the harmful event took place; rather, what matters is the fact that, due to the event, the child was born with defects that could be qualified as damage in terms of legal regulations concerning liability.
\end{abstract}

Key words: nasciturus, civil law, legal personality, damage, legal capacity, liability.

\section{INTRODUCTION}

The term nasciturus comes from Latin and means the one who is to be born, a child who is still inside his/her mother's womb. From the moment of conception until his/her birth, a child inside his/her mother's womb undergoes various stages, and nasciturus would be a general term for a child inside his/her mother, until the moment of his/her birth or at least the beginning of childbirth. Protecting nasciturus by means of the civil law leads us to the question of his/her legal personality. This particu-

* Assistant Professor at Union University School of Law

e-mail: jelena.simic@pravnifakultet.rs 
larly applies in cases of harm incurred to life, body and health prior to birth or during childbirth. That is when a question arises whether a child inside his/her mother's womb enjoys legal personality, and whether it is entitled to bodily integrity and the right to receive a compensation from those that harm his/her integrity?

Certain German jurists answered this question positively, even though the German Civil Code in $\$ 1$ prescribes that "a person's legal personality begins at the end of childbirth". ${ }^{1}$ Thus, in a discussion in one of his papers on the beginning and the end of a person's legal personality, the German jurist Wolf stated: "Research into the civil law confirmed that nasciturus does have legal personality", concluding that nasciturus, as a legal subject, can suffer harm to his/her health. ${ }^{2}$ However, a while after that, both legal theory and case law saw divided opinions in this regard. When it comes to another German legal philosopher Gustav Radbruch it could be said that: " $[\mathrm{N}]$ othing is as decisive for the style of a legal era as the conception of the person towards which it is oriented."3 Radbruch's remark underlines the vital importance of reflection on the question of what it means to be a person in law. Who is the addressee of legal norms, and how is this addressee connected to actual flesh-and-blood human beings? ${ }^{4}$

Today, the general opinion is that legal order does not equalize a conceived and unborn human with the born one, i.e. it is considered that nasciturus enjoys assumed legal personality. ${ }^{5}$ A child who dies at childbirth does not acquire legal personality either. The beginning of legal personality requires the ending of childbirth, which implies complete exit of a child from his/her mother's womb, without requiring the cutting of umbilical cord. ${ }^{6}$ According to the World Health Organization, live birth refers to the complete expulsion or extraction from its mother of a product of conception, irrespective of the duration of the pregnancy, which, after

1 Bürgerliches Gesetzbuch (BGB) - German Civil Code, (https://www.gesetze-im-internet.de/englisch_bgb/englisch_bgb.html\#p0030, 12.09. 2018).

2 Wolf, E., Naujoks, H., Anfang und Ende der Rechtsfahigkeit des Menschen, Frankfurt am Main 1955, p. 177.

3 Van Beers, B., 2017, The Changing Nature of Law's Natural Person: The Impact of Emerging Technologies on the Legal Concept of the Person, German Law Journal, Vol. 18, No.03/2017,p.560.(https://static1.squarespace.com/static/56330ad3e4b0733dcc0c8495/ t/592823bcd1758eaccfa325ae/1495802813352/04_Vol_18_No_03_van+Beers.pdf, 05.09. 2018).

$4 \quad$ Van Beers, B., 2017.

5 Vodinelić, V. V., 2014, Građansko pravo, Uvod u građansko pravo i Opšti deo građanskog prava, Pravni fakultet Univerziteta Union i Službeni glasnik, Belgrade, p. 354.

6 Brox, H., Wolf, D. W., 2006, Allgemeiner Teil des BGB, 30. Auflage, Köln, p. 360. Compare: Vodinelić, V. V., 2014, p. 347. 
such separation, breathes or shows any other evidence of life - e.g. beating of the heart, pulsation of the umbilical cord or definite movement of voluntary muscles - whether or not the umbilical cord has been cut or the placenta is attached. Each product of such a birth is considered live born. ${ }^{7}$ Also, for acquiring legal personality, it is not enough that a child was stillborn. A requirement is that it had lived at least for a moment, and a proof of certain life function is considered to be breathing and heartbeats. ${ }^{8}$ The views of contemporary jurists regarding the beginning of legal personality and the right to prenatal damage compensation are different and less disputable.

Even though nasciturus does not enjoy the legal personality of a born human, he/she is not left without civil law protection. A large contribution to this fact was made by the German Federal Constitutional Court, whose stand is that human dignity belongs to an unborn child, too. ${ }^{9}$ After nidation, nasciturus is an individual with his/her own genetic identity, which therefore makes him/her unrepeatable and unchangeable. It is no longer a life that is changeable, that develops into a human, but rather it develops as a human. ${ }^{10}$ In line with that, the partial legal personality of nasciturus must be confirmed by the constitutional law. ${ }^{11}$ However, certain German jurists do not accept the notion of the "limited legal personality" of nasciturus. They start from the fact that a child inside his/her mother's womb does not enjoy legal personality, and that the exceptions envisaged by special provisions of the German Civil Code (BGB) represent only a mitigation of $\$ 1$ BGB. They qualify these provisions as exceptions in favour of "an emerging legal subject", which is entitled only to "emerging rights". ${ }^{12}$

7 This definition was adopted by the World Health Assembly (WHA Resolutions WHA 20.19 and WHA43.24) in line with Art. 23 of the WHO Constitution. See International Statistical Classification of Diseases and Related Health Problems, pp. 1107-1108. (http://www.batut.org.rs/download/MKB102010Knjiga1.pdf, 01.09. 2018).

8 H. Brox, W. D. Wolf, 2006, p. 360.

9 A 1975 decision by the Federal Constitutional Court, BVerfGE 39, 1. The decision is entirely available in: A Selection of Decisions by German Federal Constitutional Court, Šarčević, E. (ed.), Konrad Adenauer Foundation 2009, p. 160 onward.

10 Prussian General State Law (I 1,10) involved the following provision: "General human rights belong to an unborn life from the moment of its conception."

11 Schmitt, J., 2001, Munchener Kommentar zum Burgerlichen Gesetzbuch, Band I: Allgemeiner Teil, 4. Auflage München, p. 113.

12 Gernhuber, J., Coester-Waltjen, D., 1994, Lehrbuch des Familienrechts, 4. Auflage, München, $\$ 75$ III. Compare: Haaf, L. T., 2017, Unborn and Future Children as New Legal Subjects: An Evaluation of Two Subject-Oriented Approaches-The Subject of Rights and the Subject of Interests, German Law Journal, Vol. 18, No. 05, pp. 10911120; Haaf, L. T., 2016, Future Persons and Legal Persons: The Problematic Representation of the Future Child in the Regulation of Reproduction, Laws, 5(1):10, pp. 1-16. 


\section{NASCITURUS IN THE NORMS OF CIVIL LAW}

The legal position of nasciturus is understood quite differently, not only in different states, but also in regard to the same regulations. ${ }^{13}$ His/ her property-legal capacity is regularly regulated, but differently in terms of both scope and modality, ${ }^{14}$ while virtually no provisions exist regarding the personal-legal capacity of nasciturus, even though when it comes to personal rights, a need arises from the very conception that a conceived and unborn child holds personal rights to personal properties that exist from that period. ${ }^{15}$ However, his/her protection using property sanctions is possible to a certain extent in the field of the entire civil law: law on obligations, succession, real and family law. Corresponding norms exist in civil codes and in some other regulations on this matter. Roman law recognized the following legal principle: Nasciturus pro iam nato, i.e. that the one conceived (at the time of testator's death) should be considered born, and that principle is accepted in the domestic law, as well. ${ }^{16}$ According to the German Civil Code, nasciturus is entitled to a damage compensation right for the murder of a person from whom he/she would have the right to receive support ( $\$ 844$, par. 2$).{ }^{17}$ Besides, in order to provide future right to support, it is possible to obtain a temporary order in favour of nasciturus (\$1615), and in order to preserve his/her future rights, it is possible to appoint him/her a guardian $(\$ 1912$, par. 1$) .{ }^{18}$ Furthermore, it is generally opined that in terms of contracts in favour of a third party, an unborn yet conceived and definable child can be a beneficiary. ${ }^{19}$ Following the same pattern, it is allowed to enter a mortgage in favour of an unborn child. ${ }^{20}$ It should be noted that Serbian Family Law contains a provision that protects the interest of nasciturus. It is Art. 47, which regulates the cases when paternity can be acknowledged. Its par. 2. states that "exceptionally, the acknowledgement of paternity produces an effect even if it is given prior to the child's birth, provided that the child is born

13 Vodinelić, V. V., 2014, p. 344.

14 Vodinelić, V. V., 2014, p. 350.

15 Vodinelić, V. V., 2014.

16 See Art. 3, par. 2., of the Law on Succession of the Republic of Serbia, Official Gazette of the Republic of Serbia, No. 46/95 and 101/2003 - a decision by the Constitutional Court of the Republic of Serbia.

17 BGB, Bürgerliches Gesetzbuch - German Civil Code, (https://www.gesetze-im-internet.de/englisch_bgb/englisch_bgb.html\#p0030, 12.09. 2018).

18 BGB, Bürgerliches Gesetzbuch - German Civil Code.

19 Radišić, J., 2000, Obligaciono pravo, opšti deo, šesto prerađeno i dopunjeno izdanje, Belgrade, p. 144.

20 Radišić, J., 2000. 
alive." ${ }^{21}$ In our positive law, the Law on Non-Contentious Proceedings of the Republic of Serbia, Art. 112 states that, if a child who would be entitled to inheritance is expected to be born, a probate court informs of this a guardian body. Unless the guardian body decides otherwise, one of the unborn child's parents takes care of the child's rights. ${ }^{22}$ When it comes to the protection of the succession rights of nasciturus, no difference is made between development stages in the prenatal period. A child that was already conceived at the moment of a testator's death can be a successor if he/she is born alive. ${ }^{23}$

Austrian Civil Code - ABGB, in $\$ 22$ contains a more complete norm regarding the rights of nasciturus: "From the moment of their conception, even unborn children are entitled to the protection of the law. As far as theirs, and not the rights of a third party are concerned, they are to be regarded as born; but a stillborn child, in terms of the rights reserved for a liveborn child, is to be regarded as if he/she has never acquired them." 24 The first sentence of this paragraph does not actually refer to the legal personality of nasciturus, but in its promise of legal protection it contains only the program that is to be realized by other norms of Civil and Criminal Codes. It should not lead to a conclusion that all legal norms using the term "human" cover nasciturus as well.

The second sentence of this paragraph does acknowledge the conditional and limited legal personality of nasciturus. Conditional, because it depends on livebirth (not on the capacity to live), and limited because it is limited only to its own rights. Under the rights, the Law implies not only property, but also personal rights. In regard to those rights, nasciturus enjoys partial legal personality from the moment of conception. ${ }^{25}$ However, since he/she does not hold legal capacity, a guardian needs to take care of his/her rights (\$274 $\mathrm{ABGB}){ }^{26}$

21 Family Law of the Republic of Serbia, Official Gazette of the Republic of Serbia, No. 18/2005, 72/2011 - state law and 6/2015.

22 Art. 112. of the Law on Non-Contentious Proceedings of the Republic of Serbia, Official Gazette of the Republic of Serbia, No. 46/95 - state law, 18/2005 - state law, 85/2012, 45/2013 - state law, 55/2014, 6/2015 and 106/2015 - state law.

23 Art. 3. par. 2. of the Law of Succession of the Republic of Serbia, Official Gazette of the Republic of Serbia, No. 46/95, 101/2003 - a decision by the Constitutional Court of the Republic of Serbia and 6/2015.

24 ABGB - Allgemeines bürgerliches Gesetzbuch, (https://www.jusline.at/gesetz/abgb/ paragraf/22, 05.09. 2018).

25 Aicher, J., 1983, in: Rummel, P., Kommentar zum Allgemeinen burgerlichen Gesetzbuch, 1. Band, Wien, p. 71.

26 ABGB - Allgemeines bürgerliches Gesetzbuch, (https://www.jusline.at/gesetz/abgb/ paragraf/274, 05.09. 2018). 


\section{THE PROTECTION OF THE BODILY INTEGRITY} OF NASCITURUS

When it comes to property sanctions, German legal theory and practice claim that contract and tort law protect the integrity of a child within a womb in the same way they protect the integrity of a pregnant woman during every medical procedure, prenatal examination and childbirth. ${ }^{27}$ The protection also covers harmful actions of third parties which affect the child indirectly, through the pregnant woman. It is believed that a child inside his/her mother's womb is entitled to bodily integrity; he/she is considered equal to a born child, and capable of being hurt in the sense of tort law. The circumstance that Criminal Code does not envisage a sanction for harm caused to nasciturus does not exclude the possibility of a necessary civil-legal protection of a person whose health suffered from harm in shape of prior damage caused at an embryonic stage. ${ }^{28} \mathrm{~A}$ verdict by the German Federal Supreme Court states: "A child inside his/her mother's womb is meant to enter life as a human, he/she, and the child born later are identical persons, a naturally given fact that the law must bear in mind. Damage caused to a child inside his/her mother's womb, therefore, at the end of birth, constitute damage caused to the health of a human, for which the perpetrator must provide adequate compensation" ( $\$ 823 \mathrm{BGB}) .{ }^{29}$ To be more precise, the damage that a biological organism suffered at a prenatal stage can continue after its birth in shape of physical appearance defects or the functional disability of a developed organism. In such cases, it can be confidently said that a person's health was damaged by a prenatal action. ${ }^{30}$ This point of view was confirmed by the German Federal Supreme Court. ${ }^{31}$ Its view is that nasciturus enjoys constitutional legal protection in line with Art. 1 and 2 of the German Federal Constitution. Art. 1, par. 1 states: "Human dignity shall be inviolable. All state authorities shall respect and protect it." Art. 2, par. 1 prescribes: "Every-

27 Steffen, E., Pauge, B., 2006, Arzthaftungsrecht, 10. Auflage, Köln, p. 50.

28 Laufs, A., Uhlenbruck, W., 2002, Handbuch des Arztrechts, 3. Auflage, München p. 963. See also: Simić, J., 2008, Pravna zaštita nasciturus-a i nondum conceptus-a, magistarski rad, Pravni fakultet Univerziteta Union, Belgrade, p. 76; and Simić, J., 2018, Pravni problemi definisanja pravne zaštite Nondum Conceptus-a, Strani pravni život, 3, Institute of Comparative Law, Belgrade, p. 26-27.

29 A 1972 verdict by the German Federal Supreme Court, published in: Neue Juristische Wochenschrift from 1972, pp. 1126.

30 Larenz, K., 1989, Allgemeiner Teil des deutschen Burgerlichen Rechts, 7. Auflage, München, p. 94.

31 See a decision published in: Neue Juristische Wochenschrift from 1975, p. 753. BVerfGE 39, 1, in: Izabrane odluke nemačkog Saveznog ustavnog suda, Šarčević, E. (ed.), p. 160 onward. 
one is entitled to life and bodily integrity." Therefore, the Constitutional Court concludes that a life developed inside a mother's womb as an independent legal property enjoys the protection of the Constitution. ${ }^{32}$ An embryo may be acknowledged the right to bodily integrity, because he/ she, just like a born child, may suffer a damage of legal properties, so his/ her legal personality should be acknowledged, too. However, it should be noted that, in line with $\$ 1 \mathrm{BGB}$, his/her right to damage compensation shall come into effect only after his/her birth. Considering that compensation is awarded only to a born human, some jurists believe that nasciturus enjoys "only indirect protection". 33

What is important here is the recognition of nasciturus as a separate legal subject and a holder of the right to damage compensation for bodily harm, but his/her right to file a suit is delayed until after childbirth. On one hand, this enables the involvement of nasciturus into the protection of doctor's duty of care enjoyed by a pregnant woman, and on the other hand, it allows to derive doctor's duty of care that protects the integrity of nasciturus from a medical treatment contract closed by a pregnant woman. ${ }^{34}$ Thus, one aspect involves doctor's general obligations that everyone has toward everyone, and whose violation implies tort responsibility toward nasciturus. The other aspect involves doctor's special obligations based on a contract closed with a pregnant woman, which according to German jurists, falls into the category of contracts that involve the obligation to protect third parties, whose needs the trustee cares about as much as he/she does about his/her own. If a doctor violates some of these obligations and

32 Neue Juristische Wochenschrift from 1975. It should be noted here that at the end of 1990s, several European countries introduced provisions concerning the status of an unborn child into their Constitutions. For example, the Constitutions of the Czech Republic and Slovakia in their chapters on fundamental rights and freedoms prescribed that everyone is entitled to life, and that human life shall be protected prior to birth. An even more explicit provision on the protection of an unborn life is contained in the Hungarian Law on the Protection of the Foetus, which underlines that a foetus must be respected and protected from the moment of conception. However, it can be said that Poland took the biggest step in the general protection of an unborn life when it prescribed in its changes to the The Family Planning, Human Embryo Protection and Conditions of Permissibility of Abortion Act that the right to life is an object of protection during prenatal period, and within a time limit envisaged by the law. For more information about this, see: Kandić-Popović, Z., 1999, Biotehnologija: Ka evropskoj harmonizaciji, Open Society Institute, Praha, pp. 7-10. (https://docplayer.net/34196549-Pravna-zastita-osnovnih-ljudskih-vrednosti-u-centralnoj-i-istocnoj-evropi-i-moderna-biotehnologija-ka-evropskoj-harmonizaciji-zorica-kandicpopovic.html, 12.09. 2018).

33 Bernard, A., 1995, Der Schwangerschaftsabbruch aus Zivilrechtlicher Sicht unter besonderer Berucksichtigung der Rechtsstellung des nasciturus, Berlin, p. 43.

34 Schramm, S., 1992, Der Schutzbereich der Norm im Arzthaftungsrecht, Karlsruhe, p. 109. 
causes damage to nasciturus, he/she will have to compensate for it in line with the rules of contractual liability. Even though he/she is not a contractual party, nasciturus enjoys the protection of his/her mother's contract. ${ }^{35}$

Since $\$ 823$, par. 1 BGB, establishes responsibility for a damage caused to another person, the main question would be: could nasciturus be treated as the "other" in the sense of the given paragraph. German case law and legal theory have finally concluded that nasciturus can be treated as the "other" in the sense of $\$ 823$, par. 1, but also in terms of $\$ 84$ of the Medicinal Products Act and \$7, par. 2 of the Product Liability Act. ${ }^{36}$ However, civil-legal protection of nasciturus refers only to the damage caused to his/her health, not to murder. This implies that the one who murdered nasciturus faces solely criminal responsibility for unauthorised termination of pregnancy, provided that he/she acted with premeditation. $.^{37} \mathrm{He} /$ she owes no damage compensation for murdering a child inside a mother's womb. In other words, damage compensation is possible only when a harm of the bodily integrity of nasciturus did not result in his/her death, but in damage to his/her health. ${ }^{38}$

\section{CASEs of harmful aCtions For nasciturus BASED ON GERMAN CASE LAW}

Prenatal damage (Lat. prae natalis - prior to birth) implies damage caused to a human embryo by inflicting injuries within a time period between his/her conception and childbirth. ${ }^{39}$ By accepting the point of view that human life begins with conception, and that, therefore, the bodily integrity of nasciturus equals the bodily integrity of a born person, nasciturus has been given the right to bodily integrity and he/she, just like a born child is considered to be able to suffer damage to his/her legal properties. ${ }^{40}$ What is important is that those harms disturb normal embryonic development of a child, and depending on what a harmful action involves

35 For more information on this type of contracts, see: Radišić, J., 2000, pp. 142-143.

$36 \$ 823$ Bürgerliches Gesetzbuch (BGB) (https://www.gesetze-iminternet.de/englisch_ bgb/englisch_bgb.html\#p3489, 5.09.2018); Schramm, S., 1992, p. 110.

37 Schramm, S., 1992, p. 111.

38 Bockemuhl, L., 1995, Schutz und Recht des Ungeborenen im deutschen und angloamerikanischen Recht, Aachen, p. 60.

39 For more information on this, see: Radišić, J., 2008, Medicinsko pravo, drugo prerađeno i dopunjeno izdanje, Pravni fakultet Univerziteta Union i Službeni glasnik, Belgrade, pp. 200-201.

40 Radišić, J., 2008. Also: Stojanović, D., 1970, O direktnoj odgovornosti za štete koje pretrpi još nerođeno dete, Zbornik Pravnog fakulteta u Nišu, Vol. 9, Pravni fakultet Niš, pp. 101-109. Compare: Haaf, L. T., 2017, p. 1112. 
(what type of action or inaction), when it was done or failed to be done, or at what moment the damage was perceived or manifested, it is possible to sort all the cases of harmful actions to nasciturus into several specific groups. However, the most important division is the one according to the time when a harmful action took place. From that point of view, there are two larger groups of cases. The first group comprises cases in which the action which caused a damage was done or failed to be done at the time between conception and childbirth, and the second group involves cases in which a harmful action was done or failed to be done prior to or during the conception of a nasciturus. ${ }^{41}$

Prenatal harmful actions involve the following cases:

1) A pregnant woman gets infected through blood transfusion with toxoplasmosis, lues, listeriosis or HIV, and then transmits the disease to the child in her womb.

2) A pregnant woman gets injured in a traffic accident caused by another driver, which caused her to give birth to a paraplegic child.

3) A pregnant woman gives birth to a child with severe brain damage after she suffers a shock that affected the foetus inside her womb when she finds out that her husband died in a car accident caused by another driver.

4) An employed pregnant woman suffers a severe bodily injury in a workplace accident, after which she gives birth to a child who is either sick or has a severe physical defect.

5) A pregnant woman uses a certain hypnotic drug, which causes her to give birth to a child with physical defects.

6) At birth a child suffers a bodily injury due to the negligence of an obstetrician who assisted at childbirth.

7) A doctor who monitors pregnancy fails to inform the pregnant woman of a disability in the foetus which would lead her to opt for abortion, and due to which she gives birth to a child with a severe physical defect.

8) A pregnant woman uses alcohol or drugs excessively, which causes postnatal damage to nasciturus.

9) A damage caused by the violation of the right to family planning.

A great deal of controversy is caused by the question of damage inflicted by violating the right to family planning. In these cases a question arises whether doctor's civil responsibility can arise in cases of wrongful

41 Simić, J., 2008, pp. 78-79. 
and unplanned birth of a child, caused by a lack of or by wrong medical treatment within reproductive healthcare? Or, can a child conceived or born contrary to his/her parents' plan represent a source of damage (due to costs of support) or represent damage in itself? ${ }^{42}$ Numerous dilemmas surround this question. Roughly speaking, in such cases a child is either conceived or born due to a medical error, i.e. due to the negligent actions of a medical service provider. This involves cases of erroneous or missing medical treatment, or failure to provide or wrongly provided information concerning the facts and circumstances significant for reproductive health decision-making. Most commonly, these are: poorly performed or the lack of miscarriage; poorly conducted sterilization which was supposed to prevent pregnancy; selection of an insecure sterilization method; failure to inform a pregnant woman of a risk for foetus; erroneous human genetics counselling prior to conception, which led to the birth of a genetically handicapped child; erroneous prescription of contraceptives by a pharmacist, etc. ${ }^{43}$ Such examples do not exhaust all the possible cases that lead to wrongful conception or birth, and potentially responsible persons include doctors, genetic counsellors, pharmacists, manufacturers of contraceptives, hospital administrations, and even parents. The generally accepted terms in legal theory and practice of many countries, which denote the circumstance that a child's birth or existence contradicts the will of certain persons are: wrongful birth and wrongful life, which we shall not investigate further in this article. ${ }^{44}$

For the purpose of better understanding of the aforementioned potential harmful actions for nasciturus, the following are a few characteristic examples from the German case law.

42 Radišić, J., 2008, p. 197. See also: Simić, J., 2016, Dečak ili devojčica ili osoba? Specifičnosti pravnog položaja interseks dece, in: Opšti okvir za sprovođenje prava deteta u Srbiji i položaj posebno osetljivih grupa dece, CUPS, Belgrade, p. 148.

43 Radišić, J., 2008. See also: Simić, J., 2016.

44 It is important to underline that in 2015 Serbia passed the Law on Prevention and Diagnostics of Genetic Diseases, Genetically Determined Anomalies and Rare Diseases (also known as Zoja's Law, Official Gazette of the Republic of Serbia, No. 8/2015). Zoja's Law introduced damage compensation for wrongful birth into Serbia's legal system. The Law's provisions do not regulate damage compensation for wrongful conception, because Zoja's Law regulates diagnostics, not reproduction. Its provisions lead to a conclusion that actively legitimized persons are parents and the child, with different grounds for damage compensation and different options for compensation claims. Zoja's Law does not allow for compensation due to wrongful life. Such a case is not defined by the form that a child may act as a claimant. What matters is the content of a claim. A sick child appears as a plaintiff only in relation to the costs actually incurred to him/her, not because it claims to have or suffers from a wrongful life. 


\subsection{EXAMPLE 1}

A pregnant woman was monitored and prepared for childbirth by a doctor, gynaecologist, who was the head of the hospital's gynaecology and obstetrics ward. It was established that the child occupied an unusual, socalled "breech" position, which is considered to be a "high-risk pregnancy". Therefore, at the last examination, the gynaecologist arranged with the pregnant woman to conduct a C-section, which was documented in her medical chart along with the specification that the delivery is to be conducted on April 5. However, the pregnant woman arrives to the hospital on March 31, when she was examined by deputy head of the ward, because the head of the ward was absent. Instead of a C-section, the childbirth was natural. During the childbirth, the child suffered a fracture in his/her upper left arm and paralysis in his/her right arm. The fracture was later healed, and the paralysis removed thanks to physical therapy.

The child and his/her mother filed a suit against the head of the ward and his deputy, demanding damage compensation. First and second instance courts rejected their claims. However, the Federal Supreme Court partly confirmed the rejection of the suit filed by the mother, but it abolished the second-instance court's decision in all other matters and ordered a new trial. This Court pointed to the possibility that both defending doctors may be responsible as solidary debtors to the child, but on different legal grounds. The doctor who conducted the delivery is responsible for conducting a vaginal delivery even though he was aware of the "breech position of the child". This exposed the child to a higher risk of perinatal damage, without the consent of the pregnant woman as the child's legal representative. His arbitrary intervention has the character of an unauthorized action, so it is not relevant whether the damage would have occurred if he had conducted a C-section. However, bearing in mind that he is deputy head of the ward, the head of the ward should answer for his errors as if they were his own, based on the contract with the mother which obliges him to protect the child as well. Both defendants are responsible for incurring increased costs of child support to the mother, but since the child filed a claim for the compensation of such damage, it cannot be claimed by the mother, too. ${ }^{45}$

\subsection{EXAMPLE 2}

A gynaecologist hospitalizes a pregnant woman in a hospital where he had the right to treat his inpatients. After examining the mother, he puts her under the care of a midwife who freelanced in the hospital. The

45 A verdict by the Federal Supreme Court dated Dec. 6, 1988, published in Medizinrecht, No. 3/1989, pp. 139-143. 
doctor went home, informing the midwife that he will be on standby and that she can call him if the childbirth demands. The first night the pregnant woman suffered an eclamptic seizure. The midwife called the gynaecologist, and in his presence the mother suffered another seizure. Then, using a vacuum, the gynaecologist performed the delivery, extracting the child experiencing asphyxia. The newborn was given CPR, but he/she suffered a brain damage, which left him/her permanently disabled and dependent on others.

Due to the brain damage he/she suffered during the delivery, the child filed a suit against the gynaecologist and the midwife, claiming damage compensation. The defendants are attributed responsibility for not realizing the risk of eclampsia right before the delivery, which then caused harm to the child's health. The suit stated that those seizures could have been predicted and prevented in a timely manner, among other things, by regularly measuring the pregnant woman's blood pressure, which was not done. The courts of first and second instance accepted the claims, and the revision before the Federal Supreme Court was not successful. The Federal Supreme Court entirely accepted the second-instance court's explanation and the statements in the child's suit. This court also found that by failing to obtain a vital parameter such as blood pressure at a stage of delivery represents a severe oversight by both the doctor and the midwife, which makes their responsibility undoubtable. ${ }^{46}$

\section{CONCluding REMARKS}

Legal solutions and proposals how to regulate the protection of nasciturus largely depends on ethical, philosophical and religious considerations. Some European countries' legislators make a selection between several possible solutions, particularly bearing in mind the legal culture of the social community, its customs and traditional values, as well as strategic and political stands, the ratio of political forces, the readiness to answer the challenges presented by the modern world, or technological and scientific progress, etc.

Civil law protects nasciturus from harm inflicted to his/her body and health. The damaged person can claim damage compensation from third persons, especially doctors, due to the activities that affected his/her body and health prior to birth or even prior to conception. Civil law protects the integrity of nasciturus the same way it does his/her mother's. However,

46 A verdict by the Federal Supreme Court dated Feb. 14, 1995, published in Medizinrecht, No. 9/1995, pp. 366-370. 
it should always be considered that the potential right to life of nasciturus collides with the mother's right to protect her own personality, and particularly her life and health. This is also the stand of the European Court of Human Rights, whose decisions indicate that "foetus represents an inseparable part of a pregnant woman" and that "The "life' of the foetus is intimately connected with, and cannot be regarded in isolation from, the life of the pregnant woman". ${ }^{47}$ Due to such a symbiotic relationship, the treatment of nasciturus must be conducted through his/her mother's organism, which requires her consent, too.

Nasciturus is entitled to bodily inviolability, and he/she has the capacity to experience harm as "the other one" in terms of tort law. A harm to nasciturus emerges at the moment of birth by harm caused to a human, i.e. harm in legal terms. A child acquires his/her own right to prenatal damage compensation after birth, which coincides with the acquisition of legal personality. The possibility of bodily harm of nasciturus does not depend on his/her legal personality. Even when it is said that a child acquires legal personality at birth, this does not deny the fact that his/her biological existence has its own prior history. The question when a "human life" begins and from which point it enjoys legal protection is completely different from the question at which point a person acquires legal personality. When it comes to the property rights of nasciturus, there should be more room for them in positive regulations. Our future civil code should look up to BGV and include several provisions that guarantee such rights.

\section{BIBLIOGRAPHY}

1. Aicher J., Rummel, P., 1983, Kommentar zum Allgemeinen burgerlichen Gesetzbuch, 1. Band, Wien.

2. Astrid, B., 1995, Der Schwangerschaftsabbruch aus Zivilrechtlicher Sicht unter besonderer Berucksichtigung der Rechtsstellung des nasciturus, Berlin.

3. Beers, B. van, 2017, The Changing Nature of Law's Natural Person: The Impact of Emerging Technologies on the Legal Concept of the Person, German Law Journal, Vol. 18, No. 03.

4. Bockemuhl, L., 1995, Schutz und Recht des Ungeborenen im deutschen und angloamerikanischen Recht, Aachen.

5. Brox H., Wolf, D. W., 2006, Allgemeiner Teil des BGB, 30. Auflage, Köln.

6. Gernhuber, J., Coester-Waltjen, D., 1994, Lehrbuch des Familienrechts, 4. Auflage, München.

47 ECtHR, Paton v. United Kingdom, App. No. 8416/78, Judgment of May 13, 1980. (http://www.globalhealthrights.org/wp-content/uploads/2013/10/EComHR-1980-Paton-v.-United-Kingdom-X.-v.-United-Kingdom.pdf, 10.09.2018). 
7. Haaf, L. T., 2016, Future Persons and Legal Persons: The Problematic Representation of the Future Child in the Regulation of Reproduction, Laws, MDPI, 5(1):10.

8. Haaf, L. T., 2017, Unborn and Future Children as New Legal Subjects: An Evaluation of Two Subject-Oriented Approaches-The Subject of Rights and the Subject of Interests, German Law Journal, Vol. 18, No. 5.

9. Kandić Popović, Z., 1999, Biotehnologija: Ka evropskoj harmonizaciji, Open Society Institute, Praha.

10. Larenz, K., 1989, Allgemeiner Teil des deutschen Burgerlichen Rechts, 7. Auflage, München.

11. Laufs, A., Uhlenbruck, W., 2002, Handbuch des Arztrechts, 3. Auflage, München.

12. Radišić, J., 2000, Obligaciono pravo, opšti deo, šesto prerađeno i dopunjeno izdanje, Beograd.

13. Radišić, J., 2008, Medicinsko pravo, drugo prerađeno i dopunjeno izdanje, Pravni fakultet Union i JP Službeni glasnik, Beograd.

14. Simić, J., 2016, Dečak ili devojčica ili osoba? Specifičnosti pravnog položaja interseks dece, in: Opšti okvir za sprovođenje prava deteta u Srbiji i položaj posebno osetljivih grupa dece, CUPS, Belgrade.

15. Simić, J., 2008, Pravna zaštita nasciturus-a i nondum concpetus-a, magistarski rad, Pravni fakultet Univerziteta Union, Beograd.

16. Simić, J., 2018, Pravni problemi definisanja pravne zaštite Nondum Conceptus-a, Strani pravni život, 3, Belgrade.

17. Stojanović D., 1970, O direktnoj odgovornosti za štete koje pretrpi još nerođeno dete, Zbornik Pravnog fakulteta u Nišu, 9, Pravni fakultet Niš.

18. Schmitt, J., 2001, Munchener Kommentar zum Burgerlichen Gesetzbuch, Band I: Allgemeiner Teil, 4. Auflage, München.

19. Schramm, S., 1992, Der Schutzbereich der Norm im Arzthaftungsrecht, Karlsruhe.

20. Steffen, E., Burkhard, P., 2006, Arzthaftungsrecht, 10. Auflage, Köln.

21. Šarčević, E. (ur.), 2009, Izabrane odluke nemačkog Saveznog ustavnog suda, Fondacija Konrad Adenauer.

22. Vodinelić V. V., 2014, Građansko pravo, Uvod u građansko pravo i Opšti deo gradanskog prava, Pravni fakultet Univerziteta Union i Službeni glasnik, Beograd.

23. Wolf E., Naujoks, H., 1955, Anfang und Ende der Rechtsfahigkeit des Menschen, Frankfurt am Main.

\section{LEGAL SOURCES}

1. BGB, Bürgerliches Gesetzbuch - German Civil Code.

2. Family Law of the Republic of Serbia, Official Gazette of the Republic of Serbia, No. 18/2005, 72/2011 - state law and 6/2015.

3. Law on Non-Contentious Proceedings of the Republic of Serbia, Official Gazette of the Republic of Serbia, No. 25/82, 48/88, and Official Gazette of the Republic of Serbia, No. 46/95 - state law, 18/2005 - state law, 85/2012, 45/2013 - state law, $55 / 2014,6 / 2015$ and 106/2015 - state law. 
4. Law on Succession of the Republic of Serbia, Official Gazette of the Republic of Serbia, No. 46/95, 101/2003 - a decision by the Constitutional Court of the Republic of Serbia and 6/2015.

\title{
QUOTED VERDICTS
}

1. German Federal Supreme Court verdict from 1972, published in Neue Juristische Wochenschrift in 1972.

2. German Federal Supreme Court verdict dated Feb. 5, 1985 published in Medizinrecht, Vol. 6/1985.

3. German Federal Supreme Court verdict dated Dec. 6, 1988, published in Medizinrecht, Vol. 3/1989.

4. German Federal Supreme Court verdict dated Feb. 14, 1995, published in Medizinrecht, Vol. 9/1995.

5. ECtHR, Paton v. United Kingdom, App. No. 8416/78, Judgment of May 13, 1980.

\section{ZAŠTITA NASCITURUS-A U OKVIRIMA GRAĐANSKOG PRAVA}

\author{
Jelena Simić
}

\section{REZIME}

Pravna rešenja i predlozi kako da se uredi zaštita nasciturus-a zavise dobrim delom od etičkih, filosofskih i verskih promišljanja. Zakonodavci pojedinih evropskih država vrše izbor između više mogućih rešenja, vodeći pritom računa naročito o pravnoj kulturi društvene zajednice, njenim običajima i tradicionalnim vrednostima, ali i o strateškim i političkim opredeljenjima, o odnosu političkih snaga, spremnosti da se odgovori na izazove modernog sveta ili napretka u tehnologiji, nauci i sl.

Građansko pravo štiti nasciturus od povrede tela i zdravlja. Oštećeni može zahtevati naknadu štete od trećih lica, a naročito od lekara, zbog delovanja na njegovo telo i zdravlje pre rođenja ili čak i pre začeća. Građansko pravo štiti integritet nasciturus-a na isti način kao i integritet njegove majke. Treba, međutim, stalno imati u vidu činjenicu da eventualno pravo nasciturus-a na život stoji u koliziji s pravom majke na zaštitu svoje ličnosti, a naročito vlastitog života i zdravlja. Na tom stanovištu stoji i Evropski sud za ljudska prava, koji je u svojim odlukama iskazao da je „fetus neodvojivi deo trudne žene“ $\mathrm{i}$ da je „život fetusa prisno povezan sa životom trudne žene, te da ne može biti razmatran izolovano. “48 Zbog takvog sim-

48 ECtHR, Paton v. United Kingdom, App. No. 8416/78, Judgment of May 13, 1980, (http://www.globalhealthrights.org/wp-content/uploads/2013/10/EComHR-1980-Paton-v.-United-Kingdom-X.-v.-United-Kingdom.pdf, 10.09.2018). 
biotičkog odnosa i lečenje nasciturus-a mora da se odvija kroz organizam majke, što nužno iziskuje i njen pristanak.

Nasciturus ima pravo na telesnu nepovredivost i sposoban je da bude povređen kao „drugi“ u smislu deliktnog prava. Povrede nasciturus-a postaju sa trenutkom rođenja povrede zdravlja čoveka, odnosno povrede $\mathrm{u}$ pravnom smislu. Dete stiče vlastito pravo na naknadu prenatalne štete sa dovršenjem rođenja, što se poklapa sa sticanjem pravne sposobnosti. Mogućnost telesne povrede nasciturus-a ne zavisi od njegove pravne sposobnosti. I kad se kaže da dete tek sa rođenjem stiče pravnu sposobnost, da egzistira kao ličnost u pravnom smislu, time se ne negira činjenica da njegova biološka egzistencija ima svoju raniju „predistoriju“. Pitanje kada počinje „čovekov život“ i od kada je on pravno zaštićen, jeste sasvim različito od pitanja od kog je trenutka čovek pravno sposoban. Što se tiče imovinskih prava nasciturus-a, ona bi mogla dobiti više mesta u pozitivnim propisima. Po uzoru na BGB, trebalo bi u našem budućem građanskom zakoniku utvrditi nekoliko odredaba kojima se ta prava garantuju.

Ključne reči: nasciturus, građansko pravo, pravna sposobnost, šteta, poslovna sposobnost, građanska odgovornost.

Dostavljeno Uredništvu: 16. oktobra 2018. godine Prihvaćeno za objavljivanje: 26 . novembra 2018. godine 